\title{
Effect of capsaicin and chilli on ethanol induced gastric mucosal injury in the rat
}

\author{
J Y Kang, C H Teng, A Wee, F C Chen
}

Division of

Gastroenterology,

Department of

Medicine

J Y Kang

$\mathrm{C} H$ Teng

Departments of

Pathology

A Wee

and Physiology

F C Chen

National University of Singapore, Singapore

Correspondence to: Associate Professor

J Y Kang, Division of Gastroenterology, Department of Medicine, National University Hospital, Lower Kent Ridge Road, Singapore 0511 .

Accepted for publication 12 September 1994

\begin{abstract}
Capsaicin, the pungent ingredient of chilli, is gastroprotective against experimental gastric injury when given intragastrically. Epidemiological and clinical data suggest that chilli ingestion may have a beneficial effect on human peptic ulcer disease. This study showed a gastroprotective effect of intragastric capsaicin, in doses of 2 and 5 $\mathrm{mg}$, on ethanol induced gastric mucosal injury using macroscopic, histological, scanning electron microscopic, and biochemical indices. Subcutaneous administration of $2 \mathbf{~ m g}$ of capsaicin had the same gastroprotective effect as intragastric administration. Acute intragastric administration and chronic ingestion of chilli powder in doses comparable with that consumed in humans (up to $200 \mathrm{mg}$ in single doses or $200 \mathrm{mg}$ daily for four weeks) likewise protected the gastric mucosa. Both the mucosa and gastric juice had higher mucus contents when capsaicin or chilli rather than saline or solvent was used before ethanol challenge. In control animals capsaicin also increased gastric juice mucus content although the mucosal content was unaffected. Increased gastric mucus production may therefore be one mechanism by which capsaicin and chilli exert their gastroprotective effect although an alternative explanation is that the reduction in mucosal mucus depletion is secondary to the protective effect of capsaicin and chilli.

(Gut 1995; 36: 664-669)
\end{abstract}

Keywords: capsaicin, chilli, gastric mucosal injury.

Intragastric capsaicin inhibits the development of gastric mucosal damage produced by $25 \%$ and absolute alcohol. ${ }^{1-3}$ Although the effect of capsaicin in attenuating alcohol induced macroscopic damage is well established it has not been so well studied by light or scanning electron microscopy. It is also not known whether systemic administration of capsaicin has the same gastroprotective effect. While capsaicin causes an increase in gastric mucosal blood flow and this is thought to be important for its gastroprotective action, the effect of capsaicin on gastric mucus secretion has not been determined.

Peptic ulcer frequency in Singapore varies severalfold between different races. ${ }^{4}{ }^{5}$ Changes in racial differences over three decades show that environmental factors are involved. ${ }^{4}$ One possible explanation for the racial differences is a protective effect of chilli as Malays and Indians, who consume more chilli, are less susceptible to peptic ulcer disease compared with Chinese, who consume less chilli.

The aims of this study are (a) to investigate the influence of intragastric capsaicin on ethanol induced gastric mucosal injury using macroscopic, histological, scanning electron microscopic, and biochemical indices, (b) to discover if the same dose of capsaicin given subcutaneously has the same effect, (c) to discover if short term as well as longterm administration of chilli powder can reproduce the protective effect of capsaicin, and (d) to find out if mucosal and gastric juice mucus contents are affected by the use of capsaicin and chilli.

\section{Methods}

\section{ANIMALS AND REAGENTS}

Male Sprague-Dawley rats weighing about 150 $\mathrm{g}$ were used for study 1 . For study 2 , in which chilli powder had to be given by gavage, animals weighing about $200 \mathrm{~g}$ were used as larger cannulae were required. For study 3 , in which the animals were fed for four weeks, weaned Sprague-Dawley rats weighing about $60 \mathrm{~g}$ were used. In all, 146 animals were used for assessment of gastric mucosal damage and 64 for determination of mucosal mucus content and gastric juice analysis. They were studied in groups of seven to 12 . All animals were acclimatised for one week in the animal house before the experiments. Capsaicin (Sigma) was dissolved in a solvent consisting of $10 \%$ ethanol, $10 \%$ TWEEN 80 (Sigma), and $80 \%$ isotonic saline $(0 \cdot 15 \mathrm{~N}$ sodium chloride), volume for volume. Chilli powder was obtained from KVP Trading Company, Singapore and finely ground before use. An average Indian or Malay consumes about $3 \mathrm{~g}$ of chilli and about $750 \mathrm{~g}$ of food daily. The equivalent chilli dose per rat per day was therefore $100 \mathrm{mg}(3 / 750 \times 25)$ assuming that a rat eats $25 \mathrm{~g}$ of food daily. The capsaicin content of this chilli powder measured by the Singapore Institute of Standards and Industrial Research was 478 parts per million so $200 \mathrm{mg}$ of chilli powder contain approximately $0.1 \mathrm{mg}$ of capsaicin. Clinical Research Centre (CRC) cocktail consisted of $1 \mathrm{ml}$ of Hypnorm (Janssen, Beerse, containing $0.315 \mathrm{mg}$ of fentanyl and $10 \mathrm{mg}$ fluanisone), and $1 \mathrm{ml}$ or $5 \mathrm{mg}$ of midazolam (Dormicum, Roche, Basle) in $2 \mathrm{ml}$ of distilled water. 


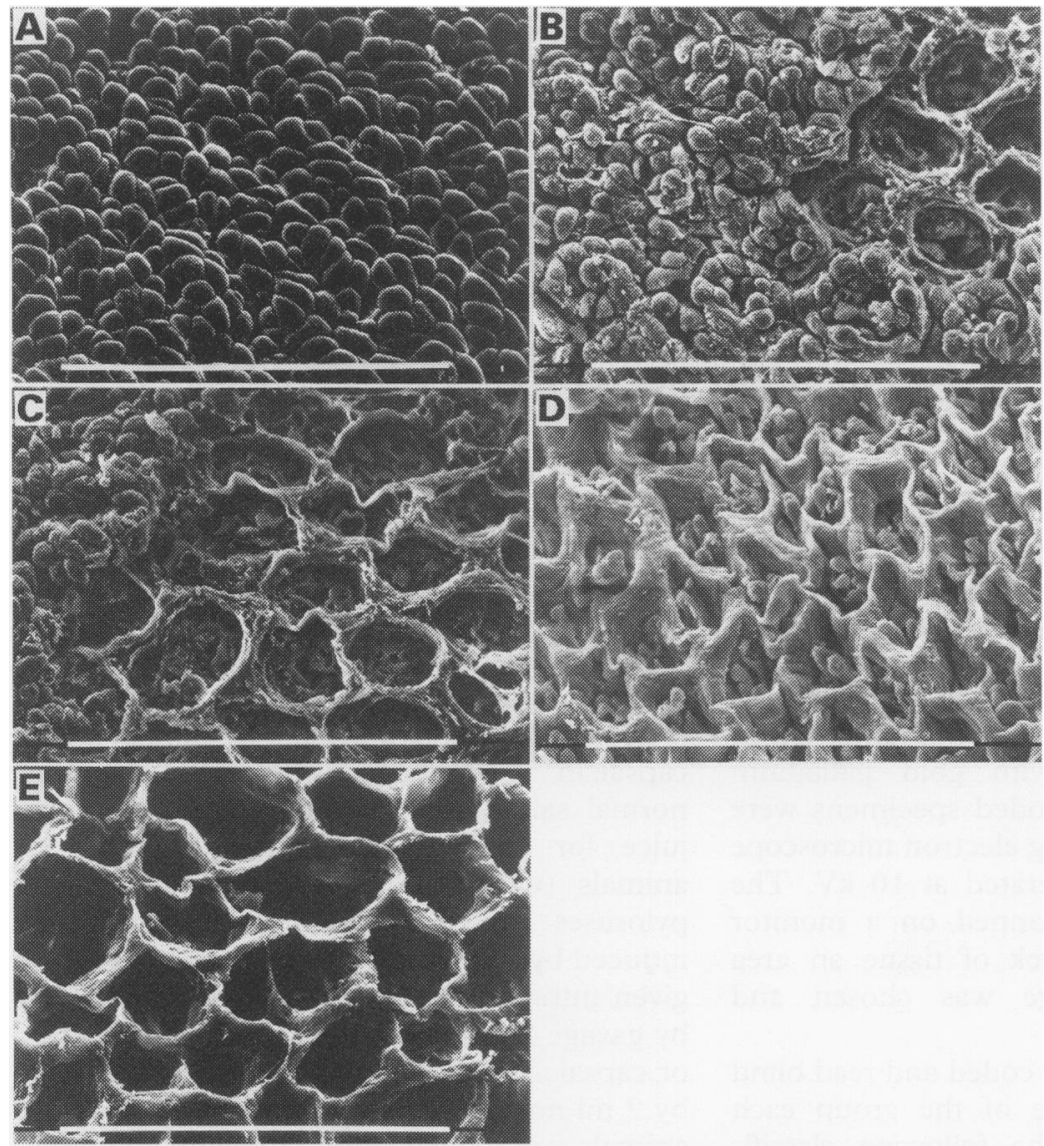

Grading of gastric mucosal damage on scanning electron microscopy. The bar represents $100 \mu \mathrm{m}$. (A) Grade 0 - no damage, normal epithelial cells cover $>90 \%$ of surface; $(B)$ grade 1 - 50-90\% of surface is covered by normal epithelial cells; (C) grade 2 - only $10-50 \%$ of surface covered by normal epithelial cells; (D) grade 3-normal epithelial cells cover $<10 \%$ of surface. Lining cells are visible in more than $50 \%$ of gastric pits; (E) grade 4 - normal epithalial cells cover $<10 \%$ of surface. Lining cells are visible in $<50 \%$ of gastric pits. absolute ethanol was given by gavage. The animals were killed after another 60 minutes.

Study 3

A further group of animals was again fasted for 24 hours but permitted full access to water. They were randomly divided into five groups and given by gavage (a) $0.5 \mathrm{ml}$ normal saline $(0.15 \mathrm{~N}$ sodium chloride), (b) $25 \mathrm{mg}$ chilli powder suspended in $0.5 \mathrm{ml}$ normal saline, (c) $50 \mathrm{mg}$ chilli powder suspended in $0.5 \mathrm{ml}$ normal saline, (d) $100 \mathrm{mg}$ chilli powder suspended in $0.5 \mathrm{ml}$ normal saline, and (e) 200 mg chilli powder suspended in $0.5 \mathrm{ml}$ normal saline. Thirty minutes later $1.5 \mathrm{ml}$ of absolute ethanol was given by gavage. The animals were killed after another 60 minutes.

\section{Study 4}

The animals were divided into two groups to receive either standard powdered rat chow $(25 \mathrm{~g}$ per day) or chow mixed with chilli powder (200 mg chilli/10 g chow). After four weeks receiving their respective diets they were fasted for 24 hours but permitted free access to water. They were then given by gavage $2 \mathrm{ml}$ of absolute ethanol and killed after 60 minutes.

\section{ASSESSMENT OF MUCOSAL DAMAGE}

\section{Macroscopic}

One hour after ethanol (or saline) administration the animals were killed by cervical dislocation. The oesophagus and pylorus were ligated and the stomach removed. The gastric contents were recovered, and the stomach cut along the greater curve and washed. It was then fixed in $10 \%$ neutral buffered formalin overnight and photographed. The amount of damage was measured by a digital planimeter (Planix 7, Tamaya Technic, Japan), and expressed as a percentage of the total glandular area. The person assessing the damage was unaware of which group each animal belonged to. $1.8 \mathrm{ml}$ normal saline $(0.15 \mathrm{~N}$ sodium chloride), (b) $2 \mathrm{mg}$ capsaicin in $0.2 \mathrm{ml}$ solvent followed after 30 minutes by $1.8 \mathrm{ml}$ normal saline, (c) $0.2 \mathrm{ml}$ solvent followed 30 minutes later by $1.8 \mathrm{ml}$ absolute ethanol, (d) $2 \mathrm{mg}$ capsaicin in $0.2 \mathrm{ml}$ solvent followed 30 minutes later by $1.8 \mathrm{ml}$ absolute ethanol, and (e) capsaicin $2 \mathrm{mg}$ in $0.2 \mathrm{ml}$ solvent given subcutaneously, and 30 minutes later, $1.8 \mathrm{ml}$ of absolute ethanol by gavage. The animals were killed after another 60 minutes.

\section{Study 2}

Before the experiment the animals were fasted for 24 hours but permitted full access to water. They were randomly divided into four groups and given by gavage (a) $0.5 \mathrm{ml}$ normal saline $(0.15 \mathrm{~N}$ sodium chloride), (b) $5 \mathrm{mg}$ capsaicin in $0.5 \mathrm{ml}$ solvent, (c) $100 \mathrm{mg}$ of chilli powder suspended in $0.5 \mathrm{ml}$ normal saline, and (c) 200 $\mathrm{mg}$ of chilli powder suspended in $0.5 \mathrm{ml}$ normal saline. Thirty minutes later $1.5 \mathrm{ml}$ of

\section{Light microscopy}

After fixation, each stomach was divided into two halves. One half was subdivided into four tissue blocks by cutting across the whole width of the half stomach. The blocks were embedded in paraffin wax. Five $\mu \mathrm{m}$ thick histological sections were cut and stained with haematoxylin and eosin. One slide containing tissue sections from all four blocks of one animal was coded and tissue damage evaluated using a modification of Lacy and Ito's classification ${ }^{6}$ as follows: (a) grade 0 - normal surface epithelial cells, gastric pits, and glands; (b) grade 1 - damage to surface epithelial cells without damage to the cells lining the gastric pits; (c) grade 2 - in addition to extensive luminal surface cell damage the cells lining the gastric pits were also disrupted and exfoliated. The gastric gland cells were not damaged; (d) grade 3 - cellular damage was evident in the 
gastric glands. The span of each degree of injury was measured microscopically with an ocular micrometer. The person evaluating the injury was unaware of the group to which each rat belonged.

\section{Scanning electron microscopy}

For the other half of each stomach, one tissue block was excised from the most abnormal looking area. The blocks were fixed in $3.5 \%$ glutaraldehyde buffered in $0.1 \mathrm{~m}$ phosphate for four hours. The specimens were then washed in phosphate buffer twice and osmicated in $1 \%$ osmium tetraoxide for two hours. After washing in distilled water and dehydration in a graded series of ethanol solutions, the specimens were dried in a critical point drying apparatus (Balzer CPD - 030) by liquid carbon dioxide, mounted on aluminium stubs and vacuum coated with gold palladium (Balzer SCD - 004). Coded specimens were then viewed in a scanning electron microscope (Phillips SEM 515) operated at $10 \mathrm{kV}$. The entire specimen was scanned on a monitor at $\times 885$. For each block of tissue an area with maximum damage was chosen and photographed.

The photographs were coded and read blind by an observer unaware of the group each animal belonged to. The following classification was used (Figure): (a) grade 0 - normal epithelial cells cover $>90 \%$ of the surface; (b) grade 1 - epithelial cells cover $50-90 \%$ of the surface, grade 2 - only $10-50 \%$ of the surface is covered by normal epithelial cells, grade 3 $<10 \%$ of the surface is covered by normal epithelial cells. Lining cells can be seen to partially fill $>50 \%$ of gastric pits, grade 4 $<10 \%$ of the surface is covered by normal epithelial cells. Lining cells are visible in $<50 \%$ of gastric pits. Each animal therefore had one score assigned to it, based on the worst affected area. Intra and interobserver agreement was 96 and $92 \%$ respectively using this grading system.

\section{MUCOSAL MUCUS CONTENT}

This was studied in separate groups of animals. The glandular portion of the stomach was removed, weighed, and kept at $-70^{\circ} \mathrm{C}$ for determination of mucus adherent to the gastric surface epithelium using alcian blue staining. ${ }^{7} 8$ This is a cationic histological dye that binds glycoproteins and soluble mucopolysaccharides into insoluble complexes without penetrating mucosal cells. The gastric glandular tissue was stained for two hours at room temperature in $10 \mathrm{ml}$ of alcian blue solution $(0.1 \%$ alcian blue dissolved in $0.16 \mathrm{M}$ sucrose and $0.05 \mathrm{M}$ sodium acetate at $\mathrm{pH} 5 \cdot 8$ ). Excess uncomplexed dye was removed by two successive rinses with $10 \mathrm{ml}$ of $0.25 \mathrm{M}$ sucrose solution for 15 and 45 minutes. Dye complexed with mucus was extracted with $10 \mathrm{ml}$ of $0.5 \mathrm{M}$ magnesium chloride solution, which was intermittently shaken for one minute at 30 minute intervals for two hours. Five $\mathrm{ml}$ of the alcian blue extract solution were then vigorously shaken with an equal volume of diethyl ether.
The amount of alcian blue in the aqueous layer was measured spectrophotometrically at 540 $\mathrm{nm}$. The quantity of alcian blue extracted was calculated from standard curves obtained from dilution of $0 \cdot 1 \%$ alcian blue solution, which obeyed the Beer-Lambert law at the dye concentration used.

\section{GASTRIC JUICE PH AND ELECTROLYTES}

The $\mathrm{pH}$ of gastric contents was measured with a pH cardymeter. (Twin pH B-112, Horiba, Kyoto, Japan). Sodium and potassium concentrations in the gastric contents were measured by compact ion meters (sodium and potassium ion meter, Horiba, Kyoto, Japan). Chloride concentrations were measured spectrophotometrically with diagnostic chloride reagents (Sigma, lot no 461-3) at $460 \mathrm{~nm}$.

In study 1 the two groups of animals given capsaicin or capsaicin solvent followed by normal saline did not have sufficient gastric juice for analysis. Therefore an extra 15 animals (weighing about $200 \mathrm{~g}$ ) had their pyloruses ligated under general anaesthesia induced by $0.33 \mathrm{ml}$ of CRC cocktail per $100 \mathrm{~g}$ given intraperitoneally. They were then given by gavage $2 \mathrm{ml}$ of either capsaicin $(10 \mathrm{mg} / \mathrm{ml})$ or capsaicin solvent followed 30 minutes later by $2 \mathrm{ml}$ normal saline. After another hour the animals were killed, their stomachs removed, and the gastric contents analysed.

\section{GASTRIC JUICE MUCUS CONTENT}

Free mucus in the gastric juice was measured by the method of Piper. ${ }^{9}{ }^{10}$ One $\mathrm{ml}$ of gastric juice was mixed with $3.3 \mathrm{ml}$ of Mcllvaine's citrate phosphate buffer ( $\mathrm{pH} 5 \cdot 8,0 \cdot 12 \mathrm{M}$ NaHPO4, $0.04 \mathrm{M}$ citrate) and $2 \mathrm{mg}$ of alcian blue at a concentration of $10 \mathrm{mg} / \mathrm{ml}$. Distilled water was added to a total volume of $5 \mathrm{ml}$. The mixture was incubated at room temperature for 24 hours and centrifuged at $2500 \mathrm{rpm}$ for 10 minutes. The concentration of alcian blue in the supernatant was estimated spectrophotometrically at $615 \mathrm{~nm}$ and compared with that in a tube containing identical reagents except that the gastric juice was replaced by buffer. The difference between the amount of alcian blue bound in the supernatant of the standard and experimental mixtures was the amount bound in insoluble complexes with the gastric mucus.

\section{STATISTICAL CONSIDERATIONS}

All results are given as mean (SEM). The Wilcoxon rank sum test was used to compare differences between groups. Probability values below 0.05 were considered significant.

\section{Results}

STUDY 1 (TABLE I)

Animals treated with saline did not show any macroscopic damage. In the rats treated with ethanol, pretreatment with capsaicin solvent was associated with more mucosal damage 
TABLE I Effect of capsaicin on ethanol induced mucosal injury

\begin{tabular}{|c|c|c|c|c|c|}
\hline Group & $\begin{array}{l}\text { Solvent/ } \\
\text { saline }\end{array}$ & $\begin{array}{l}\text { Solvent/ } \\
\text { ethanol }\end{array}$ & $\begin{array}{l}\text { Capsaicin/ } \\
\text { saline }\end{array}$ & $\begin{array}{l}\text { Capsaicin/ } \\
\text { ethanol }\end{array}$ & $\begin{array}{l}\text { Subcutaneous } \\
\text { capsaicin/ } \\
\text { ethanol }\end{array}$ \\
\hline $\begin{array}{l}\text { Macroscopic (\% damage) } \\
\text { Histological (\% damage) }\end{array}$ & 0 & $37 \cdot 9(4 \cdot 5)$ & 0 & $0.9(0.7) \dagger$ & $2 \cdot 8(1 \cdot 1) \dagger$ \\
\hline Grade 0 & $99 \cdot 0(0.6) \dagger$ & $33 \cdot 2(6 \cdot 0)$ & $100 \dagger$ & $83 \cdot 1(13 \cdot 1)^{\star}$ & $75 \cdot 7(12 \cdot 5)^{\star}$ \\
\hline Grade 1 & $1.0(0 \cdot 6) \dagger$ & $22.9(4 \cdot 5)$ & $0+$ & $12.9(9.4)$ & $12 \cdot 6(5 \cdot 3)$ \\
\hline Grade 2 & & $16 \cdot 6(5 \cdot 8)$ & $0 t$ & $0^{\star}$ & $8 \cdot 5(5 \cdot 6)$ \\
\hline Grade 3 & & $27 \cdot 3(5 \cdot 1)$ & $0 \dagger$ & $4 \cdot 0(3 \cdot 7) \dagger$ & $3 \cdot 3(2 \cdot 7) \dagger$ \\
\hline Scanning electron microscopy score & $0.9(0.5)^{\star}$ & $2 \cdot 6(0.4)$ & $0.6(0 \cdot 4)^{\star}$ & $1 \cdot 3(0 \cdot 4)^{\star}$ & $2 \cdot 5(0 \cdot 2)$ \\
\hline Mucosal mucus content $(\mu \mathrm{g} / \mathrm{g})$ & $2214 \cdot 5^{\star}(396 \cdot 4)$ & $1096 \cdot 2(88 \cdot 2)$ & $2283.6(236 \cdot 0) \dagger$ & $2377 \cdot 5(339 \cdot 1)^{\star}$ & ND \\
\hline \multicolumn{6}{|l|}{ Gastric contents } \\
\hline Volume (ml) & $2 \cdot 2(0 \cdot 1) \S$ & $2 \cdot 7(0 \cdot 2)$ & $2 \cdot 1(0 \cdot 2) \sqrt{0}$ & $2 \cdot 5(0 \cdot 2)$ & $1.9(1 \cdot 8)^{\star}$ \\
\hline $\mathrm{pH}$ & $2 \cdot 0(0 \cdot 3)$ & $6.5(0 \cdot 3)$ & $2 \cdot 3(0 \cdot 3)$ & $4 \cdot 6(0 \cdot 4) \dagger$ & $4 \cdot 3(0 \cdot 6) \dagger$ \\
\hline $\mathrm{Na}+(\mathrm{mmol} / \mathrm{l})$ & $57 \cdot 4(2 \cdot 7)$ & $137 \cdot 0(10 \cdot 9)$ & $51.9(1.5)$ & $51.2(3 \cdot 8) \dagger$ & $64 \cdot 3(13.5) \dagger$ \\
\hline $\mathrm{K}+(\mathrm{mmol} / \mathrm{l})$ & $7 \cdot 4(0 \cdot 5)$ & $20 \cdot 0(1 \cdot 6)$ & $7 \cdot 9(1.5)$ & $25 \cdot 8(1 \cdot 4)$ & $34 \cdot 3(7 \cdot 0)$ \\
\hline $\mathrm{Cl}-(\mathrm{mmol} / \mathrm{l})$ & $120 \cdot 1(3 \cdot 0)$ & $76 \cdot 0(3 \cdot 6)$ & $113 \cdot 1(3 \cdot 6)$ & $73 \cdot 3(3 \cdot 5)$ & $57 \cdot 1(4 \cdot 2)$ \\
\hline $\begin{array}{l}\text { Mucus content (mg alcian blue } \\
\text { bound/ml) }\end{array}$ & $0.36(0 \cdot 15)$ & $1.01(0.07)$ & $0.71(0.09) \ddagger$ & $1 \cdot 25(0.05)^{\star}$ & ND \\
\hline
\end{tabular}

Data presented as mean $(\mathrm{SEM}) . \mathrm{ND}=$ not done. ${ }^{\star} \mathrm{p}<0.05 v$ solvent/ethanol group; $\mathrm{tp}<0.01 v$ solvent/ethanol group; $\neq \mathrm{p}<0.05 v$ solvent/saline group; (separate groups of animals with pylorus ligation (see text).

when compared with animals pretreated with capsaicin given orally $(\mathrm{p}<0.001)$ or subcutaneously $(\mathrm{p}<0.001)$. Under light microscopy mucosal damage in the saline groups was limited to grade 1. Damage produced by ethanol was reduced by pretreatment with capsaicin given either by gavage or subcutaneously compared with the animals pretreated with capsaicin solvent. The reduction in damage was more noticeable with deep damage (grade 3) then with superficial damage (grade 1).

Mucosal damage assessed by scanning electron microscopy was again greatest in the group given ethanol after pretreatment with capsaicin solvent. Pretreatment with intragastric capsaicin reduced the damage scores $(p<0.03)$ but the reduction seen after subcutaneous capsaicin did not reach statistical significance $(\mathrm{p}=0 \cdot 13)$.

In animals treated with ethanol, pretreatment with intragastric or subcutaneous capsaicin reduced both the $\mathrm{pH}$ and sodium concentration of gastric juice compared with the use of capsaicin solvent while gastric juice volume was reduced after subcutaneous capsaicin. However, potassium and chloride concentrations were unaffected by the use of capsaicin. These data are consistent with a protective effect of intragastric and subcutaneous capsaicin as gastric mucosal damage leads to an increase in the volume, $\mathrm{pH}$, and sodium concentration of gastric contents. ${ }^{11}$

TABLE II Effect of capsaicin and chilli on ethanol induced gastric mucosal injury

\begin{tabular}{|c|c|c|c|c|}
\hline Group & Solvent & Capsaicin & $100 \mathrm{mg}$ chilli & $200 \mathrm{mg}$ chilli \\
\hline Macroscopic (\% damage) & $28 \cdot 1(8 \cdot 6)$ & $0+$ & $4.4(1.9) \dagger$ & $6 \cdot 0(1 \cdot 4)^{\star}$ \\
\hline $\begin{array}{l}\text { Histological (\% damage) } \\
\text { Grade } 0 \\
\text { Grade } 1 \\
\text { Grade } 2 \\
\text { Grade 3 }\end{array}$ & $\begin{array}{l}22 \cdot 2(7 \cdot 8) \\
18 \cdot 2(4 \cdot 9) \\
20 \cdot 0(3 \cdot 1) \\
39 \cdot 6(9 \cdot 2)\end{array}$ & $\begin{array}{l}76 \cdot 8(5 \cdot 2) \dagger \\
15 \cdot 6(3 \cdot 8) \\
6 \cdot 4(1 \cdot 6) \dagger \\
1 \cdot 2(0 \cdot 6) \dagger\end{array}$ & $\begin{array}{l}47 \cdot 6(5 \cdot 0) \dagger \\
20 \cdot 9(2 \cdot 7) \\
17 \cdot 2(3 \cdot 0) \\
14 \cdot 3(2 \cdot 8)\end{array}$ & $\begin{array}{l}58 \cdot 6(9 \cdot 3)^{\star} \\
18 \cdot 6(3 \cdot 3) \\
12 \cdot 4(5 \cdot 0) \\
10 \cdot 3(3 \cdot 5)^{\star}\end{array}$ \\
\hline $\begin{array}{l}\text { Scanning electron microscopy } \\
\text { score } \\
\text { Mucosal mucus content }(\mu \mathrm{g} / \mathrm{g}) \\
\text { Gastric contents }\end{array}$ & $\begin{array}{c}3.9(0 \cdot 1) \\
735.6(81 \cdot 4)\end{array}$ & $\mathrm{ND}^{2 \cdot 8(0.3) \dagger}$ & $\mathrm{ND}^{2.9}(0 \cdot 1) \dagger$ & $\begin{array}{c}2 \cdot 4(0 \cdot 5)^{\star} \\
1975 \cdot 3(266 \cdot 3) \dagger\end{array}$ \\
\hline $\begin{array}{l}\text { Volume (ml) } \\
\mathrm{pH} \\
\mathrm{Na}+(\mathrm{mmol} / \mathrm{l}) \\
\mathrm{K}+(\mathrm{mmol} / \mathrm{l}) \\
\mathrm{Cl}-(\mathrm{mmol} / \mathrm{l}) \\
\text { Mucus content (mg alcian } \\
\text { blue bound } / \mathrm{ml})\end{array}$ & $\begin{array}{c}4 \cdot 2(0 \cdot 3) \\
5 \cdot 9(0 \cdot 5) \\
108 \cdot 2(9 \cdot 8) \\
16 \cdot 5(1 \cdot 3) \\
69 \cdot 6(3 \cdot 9) \\
\\
0 \cdot 85(0 \cdot 08)\end{array}$ & $\begin{array}{l}2 \cdot 4(0 \cdot 4) \dagger \\
3 \cdot 7(0 \cdot 4)^{\star} \\
56 \cdot 3(7 \cdot 5) \dagger \\
30 \cdot 4(4 \cdot 7)^{\star} \\
58 \cdot 3(4 \cdot 9)^{\star} \\
\text { ND }\end{array}$ & $\begin{array}{l}3 \cdot 0(0 \cdot 3)^{\star} \\
4 \cdot 0(0 \cdot 3)^{\star} \\
88 \cdot 1(3 \cdot 4) \\
55 \cdot 0(6 \cdot 1) \dagger \\
76 \cdot 9(5 \cdot 4) \\
\text { ND }\end{array}$ & $\begin{array}{c}3 \cdot 4(0 \cdot 2) \\
3.9(0 \cdot 4)^{\star} \\
100 \cdot 7(14 \cdot 0) \\
41 \cdot 1(6 \cdot 5) \dagger \\
74 \cdot 8(4 \cdot 2) \\
1 \cdot 21(0 \cdot 10)^{\star}\end{array}$ \\
\hline
\end{tabular}

All groups given ethanol. Data presented as mean (SEM). ${ }^{\star} p<0.05$ compared with the solvent group; $t \mathrm{p}<0.001$ compared with the solvent group; $\mathrm{ND}=$ not done.
In control animals treated with saline, pretreatment with capsaicin did not affect the gastric mucosal mucus content. Intragastric instillation of ethanol depleted gastric mucosal content, an effect that was prevented by prior use of capsaicin. Capsaicin increased gastric juice mucus content compared with the use of capsaicin vehicle. The mucus content of the gastric juice after ethanol challenge was likewise increased by the prior use of capsaicin.

\section{STUDY 2 (TABLE II)}

Capsaicin pretreatment prevented ethanol induced macroscopic gastric mucosal damage. Pretreatment with 100 and $200 \mathrm{mg}$ of chilli was associated with significantly more damage but this was still significantly reduced from that seen in the control group. Similarly the two doses of chilli reduced ethanol induced microscopic damage but were less effective than $5 \mathrm{mg}$ capsaicin. The $\mathrm{pH}$ of gastric contents was reduced by both capsaicin and chilli but the reduction in the sodium concentration of gastric juice did not reach statistical significance in the two chilli groups. As with capsaicin in study 1, chilli administration increased the mucus content of both the mucosa and the gastric juice after ethanol treatment, compared with when saline was given before the ethanol.

STUDY 3 (TABLE III)

Only macroscopic assessment and analysis of gastric juice $\mathrm{pH}$ and electrolytes were performed. All chilli doses tested led to significantly less macroscopic ethanol induced damage compared with the control group in a dose dependent fashion. The gastric juice $\mathrm{pH}$ was lower in the treated groups, also in a dose related manner, but with only the two groups using the largest chilli doses achieving statistical significance over control animals. Analysis of gastric juice volume and electrolytes gave rise to variable results.

STUDY 4 (TABLE IV)

Over the four weeks of study the animals in the control group grew from $81 \cdot 7(2 \cdot 4) \mathrm{g}$ to $237 \cdot 8$ 
TABLE III Dose response study of short term chilli ingestion on ethanol induced gastric mucosal injury

\begin{tabular}{|c|c|c|c|c|c|}
\hline & Saline & $25 \mathrm{mg}$ & $50 \mathrm{mg}$ & $100 \mathrm{mg}$ & $200 \mathrm{mg}$ \\
\hline Macroscopic (\% damage) & $35.9(5.4)$ & $18.9(2.9)^{\star}$ & $15 \cdot 2(2 \cdot 9)^{\star}$ & $6 \cdot 7(2 \cdot 6) \dagger$ & $0.9(0.5) \dagger$ \\
\hline $\begin{array}{l}\text { Gastric contents } \\
\text { Volume }(\mathrm{ml}) \\
\mathrm{pH} \\
\text { Sodium }(\mathrm{mmol} / \mathrm{l}) \\
\text { Potassium }(\mathrm{mmol} / \mathrm{l}) \\
\text { Chloride }(\mathrm{mmol} / \mathrm{l})\end{array}$ & $\begin{array}{r}4 \cdot 6(0 \cdot 2) \\
6 \cdot 4(0 \cdot 3) \\
92 \cdot 6(3 \cdot 5) \\
16 \cdot 4(2 \cdot 1) \\
71 \cdot 8(2 \cdot 3)\end{array}$ & $\begin{array}{r}5 \cdot 0(0 \cdot 3) \\
5 \cdot 8(0 \cdot 5) \\
89 \cdot 8(4 \cdot 1) \\
17 \cdot 7(1 \cdot 4) \\
73 \cdot 4(2 \cdot 3)\end{array}$ & $\begin{array}{r}4 \cdot 6(0 \cdot 3) \\
5 \cdot 5(0 \cdot 4) \\
85 \cdot 2(3 \cdot 3) \\
22 \cdot 0(2 \cdot 8) \\
79 \cdot 5(2 \cdot 3)\end{array}$ & $\begin{array}{l}4 \cdot 2(0 \cdot 3) \\
4 \cdot 8(0 \cdot 3) \dagger \\
87 \cdot 4(3 \cdot 4) \\
31 \cdot 1(4 \cdot 1)^{\star} \\
73 \cdot 0(2 \cdot 9)\end{array}$ & $\begin{aligned} 4 \cdot 5(0 \cdot 2) \\
3 \cdot 7(0 \cdot 4) \dagger \\
81 \cdot 1(4 \cdot 1) \\
44 \cdot 7(4 \cdot 1) \dagger \\
75 \cdot 5(1 \cdot 3)\end{aligned}$ \\
\hline
\end{tabular}

Data presented as mean (SEM). ${ }^{\star} \mathrm{p}<0.05 v$ saline group; $\mathrm{tp}<0.01 v$ saline group.

$(5 \cdot 7) \mathrm{g}$ (mean (SEM)) while the weights of the animals in the chilli group were $85 \cdot 7(3 \cdot 1) \mathrm{g}$ at the beginning of the experiments and $248 \cdot 8$ $(7 \cdot 0) \mathrm{g}$ at the end. There were no statistically significant difference in weight gain between the two groups. The amounts of chilli taken by the rats, as calculated from the amount of chow consumed, were $252(10), 278$ (8), 326 (12), and 326 (8) $\mathrm{mg}$ per day in the first, second, third, and fourth weeks respectively.

Dietary supplementation with chilli for four weeks was associated with a reduction in ethanol induced gastric mucosal damage, both macroscopically, microscopically, and by scanning electron microscopy. Gastric juice $\mathrm{pH}$ and sodium concentrations were reduced by longterm chilli use, as in the short term situation. The animals fed with chilli had higher mucosal and gastric juice mucus contents compared with control animals.

\section{Discussion}

Intragastric capsaicin has been shown to protect the gastric mucosa against macroscopic damage produced by alcohol concentrations ranging from $25-100 \% .^{12}$ The depth of erosions produced by $25 \%$ alcohol, as measured by light microscopy, was also reduced but superficial damage as shown by light and scanning electron microscopy was said to be unaffected. ${ }^{3}$ We have confirmed this gastroprotective effect of intragastric capsaicin using macroscopic, histological, and scanning electron microscopic measurements as well as gastric juice analysis. We have also shown that this effect can be reproduced by a single dose of capsaicin given subcutaneously.

Our study showed that the gastroprotective effect of capsaicin was reproducible by acute and chronic administration of chilli powder in amounts comparable with that consumed by

TABLE IV Effect of longterm chilli ingestion on ethanol induced gastric mucosal injury

\begin{tabular}{|c|c|c|c|}
\hline Group & Control & Chilli & p Value \\
\hline Macroscopic (\% damage) & $45.9(5.9)$ & $21 \cdot 4(5 \cdot 6)$ & $<0.05$ \\
\hline \multicolumn{4}{|l|}{ Histological (\% damage) } \\
\hline Grade 0 & $36 \cdot 5(5 \cdot 8)$ & $56 \cdot 7(8 \cdot 6)$ & NS \\
\hline Grade 1 & $17 \cdot 2(8 \cdot 5)$ & $19 \cdot 7(3 \cdot 6)$ & NS \\
\hline Grade 2 & $9 \cdot 5(1 \cdot 6)$ & $7 \cdot 7(1 \cdot 8)$ & NS \\
\hline Grade 3 & $36 \cdot 8(5 \cdot 5)$ & $16 \cdot 0(4 \cdot 9)$ & $<0.01$ \\
\hline Scanning electron microscopy score & $3 \cdot 8(0 \cdot 1)$ & $2 \cdot 8(0 \cdot 3)$ & $<0.01$ \\
\hline Mucosal mucus content $(\mu \mathrm{g} / \mathrm{g})$ & $1492 \cdot 5(142 \cdot 9)$ & $2106 \cdot 2(144 \cdot 8)$ & $<0.05$ \\
\hline \multicolumn{4}{|l|}{ Gastric contents } \\
\hline Volume $(\mathrm{ml})$ & $3 \cdot 8(0 \cdot 2)$ & $3 \cdot 1(0 \cdot 2)$ & $<0.05$ \\
\hline $\mathrm{pH}$ & $6 \cdot 2(0 \cdot 2)$ & $4 \cdot 4(0.03)$ & $<0.001$ \\
\hline $\mathrm{Na}+(\mathrm{mmol} / \mathrm{l})$ & $164 \cdot 1(8 \cdot 6)$ & $112 \cdot 7(6 \cdot 9)$ & $<0.001$ \\
\hline $\mathrm{K}+(\mathrm{mmol} / \mathrm{l})$ & $25 \cdot 3(1 \cdot 6)$ & $27.9(3.6)$ & NS \\
\hline $\mathrm{Cl}-(\mathrm{mmol} / \mathrm{l})$ & $70 \cdot 3(2 \cdot 5)$ & $67 \cdot 0(3 \cdot 1)$ & NS \\
\hline Mucus content ( $\mathrm{mg}$ alcian blue bound/ml) & $0.62(0.08)$ & $1.36(0 \cdot 12)$ & $<0.001$ \\
\hline
\end{tabular}

Data presented as mean (SEM). humans. The protective effect of acute administration of chilli powder occurred in a dose dependent fashion. It is therefore possible that chilli consumption also has a protective effect on the human stomach and perhaps against peptic ulcer disease. This would explain our finding that the Chinese in Singapore who are more prone to peptic ulcer disease compared with Malays and Indians, also consume less chilli than Malays and Indians. ${ }^{45}$ Also compatible with this hypothesis are preliminary findings that (a) chilli has a gastroprotective effect on aspirin induced gastric mucosal injury in humans, ${ }^{12}$ and that (b) peptic ulcer patients consume less chilli than control patients, ${ }^{13}$ even after exclusion of those who avoid chilli use because of exacerbation of ulcer pain or fear that chilli may have an adverse effect on their ulcer disease. ${ }^{14}$

One explanation for the gastroprotective effect of chilli powder is its capsaicin content. In favour of this hypothesis is our finding that the gastroprotective effect of chilli was abolished in rats that have undergone sensory denervation (unpublished data). Another possibility is that other, as yet unidentified, ingredients of chilli powder are gastroprotective. A third possibility, that of the gastroprotective effect of chilli being caused by the physical properties of a suspension, is unlikely, as protection persisted after a 24 hour fast in the longterm experiment.

The pathophysiological basis of gastroprotection by capsaicin remains unclear. An increase in gastric mucosal blood flow has been described $^{3}$ and this may be related to release of calcitonin gene related peptide ${ }^{15}$ with the participation of nitric oxide. ${ }^{15} 16 \mathrm{Uchida}^{2}$ reported attenuation of the protective effect of capsaicin by indomethacin pretreatment but Holzer $\mathrm{et} \mathrm{al}^{3}$ reported that the protective effect of capsaicin against ethanol remained unchanged even when prostaglandin generation was inhibited by prior indomethacin administration. Holzer and Sametz ${ }^{17}$ also found that capsaicin had no effect on the capacity of gastric tissue to release prostaglandins, suggesting that the protective effect of capsaicin was unrelated to prostaglandin formation.

Mucosal mucus depletion occurred in stomachs treated with absolute ethanol. ${ }^{8}$ Pretreatment with capsaicin or chilli as well as longterm chilli use prevented the mucus depletion associated with exposure to ethanol. Capsaicin and chilli also increased the secretion of mucus into gastric juice. Capsaicin did not, however, have any effect on mucosal mucus content in animals not exposed to alcohol. It is possible that the prevention of mucus depletion is a secondary phenomenon resulting from the protective effect of capsaicin and chilli. An alternative explanation is that increased mucus production and prevention of mucus depletion upon exposure to a noxious agent are possible mechanisms by which capsaicin and chilli may exert their gastroprotective effect.

We had earlier established from pilot studies that a $2 \mathrm{mg}$ dose of capsaicin affected gastric mucosal protection for young adult rats against 
ethanol induced injury but that $5 \mathrm{mg}$ provided even better protection. The second dose was therefore chosen for the present experiments. A dose of $0.2 \mathrm{mg}$ produced an effect although in our hands this just failed to achieve significance at the $5 \%$ level. Others found doses as low as $0.1 \mathrm{mg} / 100 \mathrm{~g}$ effective. ${ }^{2} \mathrm{We}$ used up to $200 \mathrm{mg}$ of chilli powder for the short term experiments as this approached the maximum amount that can be suspended in $0.5 \mathrm{ml}$ saline. As earlier stated this dose of chilli contained $0 \cdot 1 \mathrm{mg}$ capsaicin.

Previous studies using scanning electron microscopy to study ethanol induced gastric mucosal injury have used a qualitative approach giving an overall assessment in each study group. ${ }^{311}$ However, ethanol induced gastric mucosal damage is patchy. A semiquantitative score with good reproducibility was therefore devised. Using this scoring system we have found a good correlation with macroscopic and histological evaluation and excellent discrimination between the study and control groups. The use of scanning electron microscopy, however, did not contribute any extra information in this study over and above the gross, microscopic, and functional parameters.

This work was supported by research grant RP 900309 , National University of Singapore.

1 Holzer P, Lippe I Th. Stimulation of afferent nerve endings by intragastric capsaicin protects against ethanol-induced damage of gastric mucosa. Neuroscience $1988 ; 27: 981-7$.
2 Uchida M, Yano S, Watanabe K. The role of capsaicinsensitive afferent nerves in protective effect of capsaicin against absolute ethanol-induced gastric lesions in rats. fpn f Pharmacol 1991; 55: 279-82.
3 Holzer P, Pabst MA, Lippe I Th, Peskar BM, Peskar BA, Livingston $\mathrm{EH}$, et al. Afferent nerve-mediated protection against deep mucosal damage in the rat stomach. Gastroenterology 1990; 98: 838-48.

4 Kang JY, Peptic ulcer surgery in Singapore 1951-80 with particular reference to racial differences in incidence. Aust NZ fMed 1985; 15: 604-8.

5 Kang JY, LaBrooy SI, Yap I, Guan R, Lim KP, Math MV et al. Racial differences in peptic ulcer frequency in $e t$ al. Racial differences in peptic ulcer frequency
Singapore. $\mathcal{F}$ Gastroenterol Hepatol 1987; 2: 239-44.

6 Lacy ER, Ito S. Microscopic analysis of ethanol damage to rat gastric mucosa after treatment with a prostaglandin. Gastroenterology 1982; 83: 619-25.

7 Corne SJ, Morrissey SM, Woods RJ. A method for the quantitative estimation of gastric barrier mucus. $\mathcal{F}$ Physio 1974; 242: 116-7P.

8 Wong SH, Ogre CW, Cho $\mathrm{CH}$. The influence of chronic or acute nicotine pre-treatment on ethanol induced gastric ulceration in the rat. $\mathcal{F}$ Pharm Pharmacol 1986; 38: u37-40.

9 Piper DW, Whitecross D, Leonard P, Clarke A Alcian blue binding properties of gastric juice. GastroAlcian blue binding propert

10 Bolton JP, Palmare D, Cohen MM. Stimulation of mucus and non-parietal cell secretion by the E2 prostaglandins. Dig Dis Sci 1978; 23: 359-64.

11 Tarnawski A, Hollander D, Stachura J, Krause WJ, Gergely $\mathrm{H}$. Prostaglandin protection of the gastric mucosa against alcohol injury - a dynamic time-related process. Gastroenterology 1985; 88: 334-51.

12 Yeoh KG, Kang JY, Yap I, Guan R, Tan CC, Wee A, et al. Chilli protects against aspirin-induced gastroduodenal mucosal injury in humans. Dig Dis Sci (in press).

13 Kang JY, Yeoh KG, Chia HP, Lee HP, Chia YW, Guan R, et al. Chilli-protective factor against peptic ulcer? Dig Dis Sci (in press)

14 Kang JY, Tay HH, Guan R. Chronic upper abdominal pain site and radiation in various structural and functional disorders, and the effect of various foods. Gut 1992; 33: 743-8.

$15 \mathrm{Li}$ DS, Raybould HE, Quintero E, Guth PH. Role of calcitonin gene-related peptide in gastric hyperemic response to intragastric capsaicin. Am f Physiol 1991; 261: G657-61.

16 Lambrecht N, Burchert $M$, Respondek M, Muller KM Peskar BM. Role of calcitonin gene-related peptide and nitric oxide in the gastroprotective effect of capsaicin in nitric oxide in the gastroprotective effect of
the rat. Gastroenterology 1993; 104: 1371-80.

the rat. Gastroenterology 1993; 104: $1371-80$.
17 Holzer P, Sametz W. Gastric mucosal protection against ulcerogenic factors in the rat mediated by capsaicinsensitive afferent neurones. Gastroenterology 1986; 91: 975-81. 